Situs Jurnal : http://ejurnal.stiepancasetia.ac.id/index.php/jieb

Jilid 4 Nomor 3 November 2018

Hal 330 - 341

\title{
FAKTOR-FAKTOR YANG MEMPENGARUHI PEROLEHAN KREDIT OLEH PENGUSAHA MIKRO
}

\section{Abdul Azis Safii* dan Tri Suwarno}

Abstract: The number of micro-entrepreneurs and the dominant number of micro enterprises compared to medium and large-scale enterprises in Indonesia are not balanced by the provision of access to credit and venture capital for micro businesses. This resulted in a micro-sector sector identical to the poor being vulnerable to exploitation by moneylenders who exploit the difficulties of micro entrepreneurs accessing credit from the banking sector. This study examines the factors that determine the accessibility of credit by micro entrepreneur in Bojonegoro regency. A total sum of 270 micro entrepreneurs who have applied for banking loan were sampled from the study area. With an binary logistic regression model the research resulting that education, skill on entrepreneur, and monthly net profits generated by the microenterprise are significant in determining the accessibility of microcredit.

Keywords: micro entrepreneur, microcredit, credit accessibility

Abstrak: Perkembangan jumlah pengusaha mikro serta dominannya jumlah usaha mikro dibandingkan dengan usaha menengah dan usaha besar di Indonesia, tidak diimbingi dengan penyediaan akses kredit dan modal usaha bagi para pelaku usaha mikro. Hal tersebut mengakibatkan sektor usaha mikro yang identik dengan masyarakat miskin rentan dieksploitasi oleh rentenir yang memanfaatkan sulitnya para pengusaha mikro mengakses kredit dari sektor perbankan. Penelitian ini menggunakan data primer yang di ambil langsung dari pengusaha mikro dengan teknik kuesioner. Analisis data dengan metode binary logistic regression mendapatkan hasil variabel yang berpengaruh signifikan terhadap akses kredit para pengusaha mikro adalah variabel usia pengusaha, laba bersih usaha tiap bulan, dan jumlah karyawan yang di pekerjakan.

Kata kunci : usaha mikro, microcredit, akses kredit.

\section{Latar Belakang}

Kemudahan akses kredit oleh para pelaku usaha mikro, kecil, dan menengah (UMKM) merupakan salah satu pembahasan kunci dalam proses pembangunan di setiap Negara (Kasali, Aznor, \& Lim, 2016). Dalam jangka panjang pemberian akses kredit bagi UMKM diharapkan tidak hanya menjadi solusi masalah permodalan bagi para pelaku usaha menengah kebawah, namun akan memberi efek dalam penyediaan lapangan kerja dan pada akhirnya menjadi jalan dalam pengentasan kemiskinan.

Jumlah UMKM terus mengalami peningkatan, peningkatan sebesar 2,41 persen dari tahun 2012 hingga tahun 2013, yaitu mencapai 57,89 juta unit usaha pada tahun 2013 dimana 98,77 persen diantaranya merupakan usaha mikro (Kementrian Koperasi dan UMKM, 2014). Tabel 1 menunjukan bahwa Usaha Mikro, Kecil dan Menengah (UMKM) di Indonesia mempunyai peranan signifikan terhadap perekonomian nasional khususnya Produk Domestik 
Bruto (PDB) dan penyerapan tenaga kerja. Kontribusi UMKM terhadap PDB nasional tahun 2012 tercatat sebesar 4.869,8 Triliun rupiah atau 59,8\% dari total kontribusi usaha terhadap PDB Nasional, sedangkan tahun 2013. sebesar Rp 5.440,50 triliun dan mampu menyerap tenaga kerja sebesar 107,6 juta tenaga kerja pada tahun 2012 dibandingkan dengan sektor usaha skala besar yang hanya mampu menyerap tenaga kerja sejumlah 3,2 juta tenaga kerja pada tahun yang sama. Sementara tahun 2013 penyerapan tenaga kerja oleh sektor UMKM naik menjadi 114 juta tenaga kerja sementara pada sektor usaha besar hanya menyerap tenaga kerja sejumlah 3,5 juta tenaga kerja. Baik pada kontribusi terhadap Produk Domestik Bruto (PDB) Nasional ataupun kontribusi UMKM terhadap penyerapan tenaga kerja, kontribusi terbesar diberikan oleh kelompok usaha mikro.

Tabel 1. Perkembangan Data Usaha Mikro, Kecil, dan Menegah (UMKM) dan Usaha Besar Tahun 2012-2013

\begin{tabular}{|c|c|c|c|c|c|c|c|c|}
\hline \multirow[t]{3}{*}{ Indikator Usaha } & \multicolumn{4}{|c|}{ Kontribusi atas PDB } & \multicolumn{4}{|c|}{ Penyerapan Tenaga Kerja } \\
\hline & \multicolumn{2}{|c|}{ Tahun 2012} & \multicolumn{2}{|c|}{ Tahun 2013} & \multicolumn{2}{|c|}{ Tahun 2012} & \multicolumn{2}{|l|}{ Tahun 2013} \\
\hline & (Rp Miliar) & $\%$ & (Rp Miliar) & $\%$ & (Orang) & $\%$ & (Orang) & $\%$ \\
\hline Usaha Mikro & 2.951 .120 & 35,81 & 3.326 .564 & 36,90 & 99.859 .517 & 90,12 & 104.144 .082 & 88,90 \\
\hline Usaha Kecil & 798.122 & 9,68 & 876.385 & 9,72 & 4.535 .970 & 4,09 & 5.570 .231 & 4,73 \\
\hline Usaha Menengah & 1.120 .325 & 13,59 & 1.237 .057 & 13,72 & 3.262 .023 & 2,94 & 3.949 .385 & 3,36 \\
\hline \multirow{2}{*}{$\begin{array}{l}\text { Total UMKM } \\
\text { Usaha Besar }\end{array}$} & 4.869 .568 & 59,8 & 5.440 .007 & 60,34 & 107.657.509 & 97,16 & 114.144.082 & 96,99 \\
\hline & 3.372.296 & 40,92 & 3.574.943 & 39,66 & 3.150 .645 & 2,84 & 3.537 .162 & 3.01 \\
\hline
\end{tabular}

Sumber: Kementrian Koperasi dan UKM, 2014

Berbanding terbalik dengan jumlah unit usaha mikro yang dominan dibandingkan dengan jenis usaha lainnya (usaha kecil, usaha menengah, dan usaha besar) ataupun besarnya kontribusi usaha mikro terhadap Produk Domestik Bruto (PDB) serta penyerapan tenaga kerja, dari sisi penerimaan kredit jenis usaha mikro justru mendapatkan porsi penyaluran kredit paling kecil dari perbankan nasional dibandingkan jenis usaha lainnya. Dari Tabel 2 terlihat bahwa usaha mikro menerima kucuran kredit sebesar 113,7 Triliun Rupiah atau hanya sebesar $4,1 \%$ dari total kredit usaha disalurkan perbankan pada tahun tersebut. Selama tahun-tahun berikutnya jumlah penyaluran kredit untuk jenis usaha mikro juga hanya berkisar sejumlah 4\% dari total kredit usaha yang disalurkan perbankan, tahun 2013 sebesar 4,1\% tahun 2014 sebesar 4,8\% dan pada tahun 2015 sebesar 4,8\%.

Tabel 2. Perkembangan Kredit Usaha Mikro, Kecil, dan Menegah (UMKM) dan Kredit Non UMKM oleh Perbankan Tahun 2012-2015

\begin{tabular}{lcccccccc}
\hline \multicolumn{1}{c}{$\begin{array}{l}\text { Indikator } \\
\text { Kredit }\end{array}$} & \multicolumn{2}{c}{2012} & \multicolumn{2}{c}{2013} & \multicolumn{2}{c}{2014} & \multicolumn{2}{c}{2015} \\
\cline { 2 - 8 } & (Rp Miliar) & $\%$ & (Rp Miliar) & $\%$ & (Rp Miliar) & $\%$ & (Rp Miliar) & $\%$ \\
\hline $\begin{array}{l}\text { Kredit Usaha } \\
\text { Mikro }\end{array}$ & $113,754.1$ & $4.1 \%$ & $137,797.7$ & $4.1 \%$ & $179,748.3$ & $4.8 \%$ & $199,123.4$ & $4.8 \%$ \\
\hline $\begin{array}{l}\text { Kredit Usaha } \\
\text { Kecil }\end{array}$ & $169,882.5$ & $6.1 \%$ & $193,060.3$ & $5.7 \%$ & $224,348.3$ & $5.9 \%$ & $239,194.5$ & $5.7 \%$ \\
\hline $\begin{array}{l}\text { Kredit Usaha } \\
\text { Menengah }\end{array}$ & $268,589.5$ & $9.7 \%$ & $308,613.5$ & $9.1 \%$ & $363,481.1$ & $9.6 \%$ & $392,338.3$ & $9.4 \%$ \\
\hline $\begin{array}{l}\text { Total Kredit } \\
\text { UMKM }\end{array}$ & $\mathbf{5 5 2 , 2 2 6 . 1}$ & $\mathbf{1 9 . 9 \%}$ & $\mathbf{6 3 9 , 4 7 1 . 5}$ & $\mathbf{1 8 . 9 \%}$ & $\mathbf{7 6 7 , 5 7 7 . 7}$ & $\mathbf{2 0 . 3 \%}$ & $\mathbf{8 3 0 , 6 5 6 . 2}$ & $\mathbf{1 9 . 9 \%}$ \\
\hline $\begin{array}{l}\text { Kredit Non } \\
\text { UMKM }\end{array}$ & $\mathbf{2 , 2 2 6 , 7 3 1 . 2}$ & $\mathbf{8 0 . 1 \%}$ & $\mathbf{2 , 7 4 4 , 7 5 8 . 9}$ & $\mathbf{8 1 . 1 \%}$ & $\mathbf{3 , 0 1 2 , 5 3 6 . 6}$ & $\mathbf{7 9 . 7 \%}$ & $\mathbf{3 , 3 4 5 , 7 8 7 . 0}$ & $\mathbf{8 0 . 1 \%}$ \\
\hline
\end{tabular}

Sumber: Bank Indonesia, 2017 
Sektor perbankan merupakan sumber permodalan terbesar yang dapat dimanfaatkan oleh pelaku bisnis. Namun industri perbankan yang diselenggarakan atas pertimbangan komersial membuat UMKM khususnya kelompok usaha mikro sulit memenuhi persyaratan teknis dalam mendapatkan kredit, terutama masalah agunan, kelayakan usaha, dan persyaratan administratif lainnya. Prinsip kehati-hatian perbankan dalam menyalurkan kredit atau sering disebut dengan prinsip 5C, yaitu Character (karakter), Capacity (kemampuan mengembalikan utang), Collateral (jaminan), Capital (modal), dan Condition (situasi dan kondisi) menjadi penghambat utama bagi usaha mikro untuk mengakses sumber modal (Nengsih, 2015).

Kelangkaan sumber permodalan berupa kredit untuk sektor UMKM pada dasarnya telah menjadi topik yang telah lama dibahas pada negara berkembang termasuk Indonesia. Pemerintah telah mengeluarkan berbagai kebijakan untuk mempermudah akses UMKM dalam mendapatkan pinjaman modal dari pasar uang. Salah satu kebijakan yang cukup potensial untuk mendukung kemudahan akses UMKM terhadap permodalan adalah keharusan bank komersial untuk memberikan minimal 20\% dari total kredit yang disalurkannya bagi pengembangan UMKM. Kebijakan yang bersifat konstitusional ini juga diikuti dengan dilaksanakannya berbagai pemberian pinjaman modal dalam lingkup pembangunan sektoral maupun kedaerahan, serta berbagai kebijakan yang secara langsung memberikan bantuan modal baik berupa pinjaman maupun pemberian hibah, telah diberikan dalam berbagai bentuk seperti program-progaram perkuatan dalam rangka memperkuat permodalan UMKM yang dilakukan oleh Kementrian Koperasi dan UKM untuk memberikan solusi bagi para pelaku usaha berskala kecil dan mikro yang kesulitan untuk menembus akses permodalan dari sektor perbankan. Namun program-program yang telah dijalankan seperti Gerakan Terpadu Pengentasan Kemiskinan (Gerdu-Taskin) dan Program Nasional Pemberdayaan Masyrakat Mandiri (PNPM) tidak mampu memenuhi kebutuhan kredit bagi UKM karena jumlah kredit yang dianggarkan untuk dikucurkan tidak sebanding dengan jumlah pelaku bisnis yang beskala kecil dan mikro (Yulistiyono, 2015) \& (Khoiruddin \& Heryanto, 2015).

Microcredit atau pembiayan modal yang secara spesifik ditujukan bagi sektor usaha mikro yang identik dengan masyarakat misikin adalah masalah klasik dalam perekonomian suatu negara (Haryadi, 2006). Ketersediaan permodalan yang secara mudah dijangkau oleh pelaku usaha mikro merupakan kebijakan yang sangat penting, karena pada dasarnya kelompok inilah yang selalu menjadi korban eksploitasi oleh rentenir. Salah satu penyebabnya adalah tidak adanya pasar keuangan yang sehat dan accesable bagi masyarakat lapisan bawah tersebut.

Kota Bojonegoro sebagai kota kecil di daerah Jawa Timur memiliki potensi yang besar bagi pengembangan Usaha Mikro Kecil dan Menengah. Kota Bojonegoro memiliki pertumbuhan perdagangan dan industri yang cukup tinggi di Jawa Timur, terbukti dengan perkembangan baik di sektor jasa, perdagangan dan industri setiap tahunnya. Dari data BPS Bojonegoro (2015) jumlah pelaku usaha di Kabupaten Bojonegoro dengan jumlah total 76.050 unit usaha, $98.38 \%$ diantaranya merupakan usaha mikro.

Berdasarkan data Biro Pusat Statistik Jawa timur (2016), tingkat kemiskinan di Kabupaten Bojonegoro pada tahun 2015 adalah sebesar 15,41\% atau daerah tingkat kemiskinan peringkat ke 8 di Jawa Timur, sehingga perluasan akses kredit sebagai sumber permodalan sektor usaha mikro diharapkan menjadi bagian sebagai strategi pengentasan kemiskinan di Kabupaten Bojonegoro.

Sektor usaha mikro yang identik dengan kelompok masyarakat miskin memerlukan akses permodalan dalam rangka keberlanjutan dan pengembangan usaha mereka. Dengan pinjaman kredit masyarakat miskin dapat menciptakan lapangan kerja sendiri, dan sebagian diantaranya dapat memperkerjakan seluruh anggota keluarganya, dan bahkan atau orang lain. Sehingga analisis mengenai akses kredit bagi kelompok usaha mikro selain diarahkan sebagai 
strategi pengentasan kemiskinan, juga penting dalam rangka pengurangan angka pengangguran di setiap daerah (Kalirajan \& Singh, 2009). Penelitian ini bertujuan untuk mengungkapkan faktor-faktor yang mempengaruhi perolehan kredit oleh usaha mikro dengan area penelitian di Daerah Bojonegoro.

\section{Kajian Literatur}

Usaha Mikro adalah usaha produktif milik orang perorangan dan/atau badan usaha perorangan yang memenuhi kriteria Usaha Mikro sebagaimana diatur dalam Undang-Undang bukan cabang perusahaan yang dimiliki, dikuasai, atau menjadi bagian baik langsung maupun tidak langsung dari usaha menengah atau usaha besar sebagaimana dimaksud dalam UndangUndang. Dengan kekayaan bersih paling banyak Rp 50 juta tidak termasuk tanah dan bangunan atau memiliki hasil penjualan tahunan paling banyak Rp 300 juta (Undang-Undang No. 20 Tahun 2008).

Usaha mikro mempunyai peran yang penting dalam pembangunan ekonomi, karena intensitas tenaga kerja yang relatif lebih tinggi dan investasi yang lebih kecil, sehingga usaha mikro lebih fleksibel dalam menghadapi dan beradaptasi dengan perubahan pasar (Sutrisno \& Lestari, 2006). Hal ini menyebabkan usaha mikro tidak terlalu terpengaruh oleh tekanan eksternal, karena dapat mengurang impor dan memiliki kandungan lokal yang tinggi. Oleh karena itu pengembangan usaha mikro dapat memberikan kontribusi pada diversifikasi ekonomi dan perubahan struktur sebagai prakondisi pertumbuhan ekonomi jangka panjang yang stabil dan berkesinambungan. Disamping itu tingkat penciptaan lapangan kerja lebih tinggi pada usaha mikro dari pada yang diciptakan kelompok perusahaan besar.

Dengan mempertimbangkan kelangkaan modal dalam negeri dan tingginya pertumbuhan angkatan kerja yang berlanjut, maka perkembangan usaha mikro merupakan elemen kunci dalam setiap strategi penciptaan lapangan kerja dalam negeri. Daya saing ekonomi nasional dipengaruhi oleh daya saing dan kondisi usaha mikro. Sebagai pemasok input, komponen dan jasa, usaha mikro mempengaruhi daya saing perusahaan besar, termasuk investor asing yang dapat menciptakan peluang pasar usaha mikro. Dengan demikian pengembangan usaha mikro merupakan elemen terpadu dalam strategi daya saing nasional dan terkait erat dengan kebijakan promosi dan investasi. Di Indonesia terutama didaerah pengembangan usaha mikro menjadi kunci dalam usaha mengatasi kemiskinan dan pembangunan ekonomi daerah yang lebih berimbang (Sutrisno \& Lestari, 2006).

Kredit Mikro/ Microcredit merupakan pembiayaan dengan skala mikro, makna mikro dalam dalam konteks ini berkaitan dengan nilai transaksi dan kapasitas keuangan nasabah yang umumnya masuk ke dalam kategori miskin seperti yang dirumuskan oleh UNCDF, CGAP dan ADB "microfinance refers to loans, savings, insurance, transfer services and other financial products targeted at low-income clients" (Kalirajan \& Singh, 2009).

Bank Indonesia mendefinisikan Kredit Mikro sebagai kredit dengan plafon pinjaman kurang dari Rp.50 juta dan terdiri dari kredit modal kerja, kredit investasi dan kredit konsumsi (Bank Indonesia, 2006). Kredit mikro menjadi populer karena "metode kontroversial" dikembangkan di negara miskin, karena bank komersial sulit untuk memenuhi permintaan kredit dari rakyat yang tidak memiliki agunan fisik (physical collateral) tetapi layak mendapat kredit (creditworthy) (Hollis \& Sweetm an, 1998).

Microcredit mengandung tiga elemen utama yang membedakannya dengan sistem intermediasi keuangan lainnya seperti perbankan yaitu (Jhonson \& Morduch, 2008): 1) Batasan transaksi, nilai transaksi microcredit tidak bersifat universal artinya tidak ada konvensi internasional yang menetapkan nilai transaksi yang masuk kategori kecil atau mikro. Di Indonesia, nilai transaksi microcredit hanya dirumuskan pada batasan kredit mikro saja yakni maksimum Rp 50 juta. Sedangkan untuk batasan lain terkait penyaluran kredit mikro, seperti asuransi kredit, remittance, dan sistem pembayaran, tidak ada pengaturan yang jelas. 
2) Segment Pasar microcredit memiliki keunikan dalam melayani masyarakat yakni terfokus pada masyarakat miskin 3) Tujuan, State of practice microcredit adalah untuk menanggulangi masalah-masalah yang berkaitan dengan kemiskinan.

Secara empiris, efektivitas dari penyaluran kredit mikro memberikan dampak yang positif terhadap masyarakat miskin (Setyari, 2012). Secara umum mekanisme dampak tersebut dapat dijelaskan dan digambarkan sebagai berikut: Pertama, akses keuangan yang berkelanjutan merupakan faktor produksi penting dalam kegiatan ekonomi masyarakat miskin yang dalam hal ini menghasilkan double impact yaitu pendapatan dan penyerapan tenaga kerja. Adanya pendapatan yang stabil akan mempermudah untuk mencukupi kebutuhan dasar sehari-hari, pakaian, pendidikan, kesehatan dan kebutuhan tempat tinggal yang layak, kendaraan, barang berharga, dan sebagainya. Dalam jangka panjang, akan mendorong terbentuknya rumah tangga yang mandiri dan sejahtera. Kedua, adanya jaminan pembiayaan modal mendorong pengusaha mikro mengambil keputusan bisnis jangka panjang dan melakukan investasi yang menguntungkan. Dan yang ketiga, bahwa dengan adanya suntikan modal bagi warga miskin untuk berwirausaha akan mendorong inisiatif pelaku usaha mikro untuk mengembangkan produk dan jasa keuangan lainnya untuk melayani masyarakat miskin.

Fungsi kredit pada dasarnya ialah pemenuhan jasa untuk melayani kebutuhan masyarakat dalam rangka mendorong dan melancarkan produksi, perdagangan dan konsumsi, sehingga pada akhirnya akan menaikkan pendapatan masyarakat (Firdaus \& Maya, 2004). Fungsi-fungsi kredit secara spesifik meliputi: (1) mendorong tukar menukar barang dan jasa, (2) mengaktifkan alat pembayaran yang idle, (3) menciptakan alat pembayaran baru, (4) sebagai alat pengendalian harga, dan (5) meningkatkan kegunaan (utility) potensi-potensi ekonomi yang ada.

Lembaga perbankan sebagai sumber pembiayaan serta modal bagi para pelaku usaha, berdasarkan data historis Bank Indonesia (2017) hanya memberikan porsi kecil penyaluran kredit kepada kelompok usaha mikro yang identik dengan masyarakat miskin. Hal itu disebabkan adanya anggapan bahwa kredit usaha mikro memiliki biaya traksaksi yang tinngi serta sulitnya mengukur berbagai rasio serta ukuran kesehatan keuangan kelompok usaha mikro karena pada umumnya keuangan usaha mereka tidak dipisahkan dengan keuangan private keluarga (Kasali, Aznor, \& Lim, 2016). Hal tersebut yang mendorong tumbuhnya lembaga-lembaga tidak resmi termasuk para rentenir yang memanfaatkan ketidakmampuan pelaku usaha mikro mendapatkan modal dari kredit.

Akses ke microcredit dapat meyediakan modal kerja bagi usaha skala mikro yang selanjutnya dapat menghasilkan laba yang lebih besar, menciptakan lapangan kerja, dan lebih jauh dapat membantu pengentasan kemiskinan. Dan sebaliknya ketidakmampuan pelaku usaha mikro dalam mengakses pembiayaan karena ketatanya persyaratan yang ditetapkan oleh pemberi kredit, serta sulitnya sektor mikro untuk memenuhi persyaratan kredit mikro tersebut maka akan menambah angka kemiskinan (Ali, et al, 2013)

Dalam analisis penyaluran kredit kepada pengusaha skala mikro tentu juga harus dilakukan pembahasan mengenai kelayakan penyaluran kredit kepada masyarakat mereka. Seperti telah disampaikan sebelumnya bahwa konsep microcredit menjadi pembahasan yang mendesak untuk diselesaikan karena ketidak-mampuan sektor mikro untuk memenuhi persyaratan pengajuan modal dari perbankan. Sehingga konsep 5C penyaluran kredit tidak diterapkan untuk analisis kredit pada masyarakat miskin.

Dalam penelitian ini sebagai gambaran kelayakan penyaluran kredit modal usaha peneliti menggunakan benchmark data jumlah penyaluran kredit secara global oleh perbankan di Indonesia antara tahun 2011 hingga tahun 2013. 
Tabel 3. Jumlah Penyaluran Kredit dan Non Performing Loan pada Sektor UMKM dan MKM oleh Perbankan di Indonesia (dalam Milyar Rupiah)

\begin{tabular}{llll}
\hline & $\mathbf{2 0 1 1}$ & $\mathbf{2 0 1 2}$ & $\mathbf{2 0 1 3}$ \\
\hline Kredit pada Usaha Kecil dan Mikro & & & \\
\hline Jumlah Kredit disalurkan & 458.164 & 526.397 & 608.828 \\
\hline Jumlah Kredit Macet & 15.674 & 17.011 & 19.515 \\
\hline Prosentase Kredit Macet & $3.42 \%$ & $3.23 \%$ & $3.21 \%$ \\
\hline \multicolumn{4}{l}{} \\
\hline Kredit pada Usaha Menengah keatas & & & \\
\hline Jumlah Kredit disalurkan & 1.151 .392 & 1.350 .606 & 1.562 .104 \\
\hline Jumlah Kredit Macet & 26.115 & 31.714 & 37.022 \\
\hline Prosentase Kredit Macet & $2.27 \%$ & $2.35 \%$ & $2.37 \%$ \\
\hline
\end{tabular}

Sumber: Otoritas Jasa Keuangan, 2015

Dari Tabel 3 tampak bahwa walaupun presntase kredit bermasalah penyaluran kredit pada sektor UMKM lebih tinggi daripada presentase kredit bermasalah pada usaha-usaha menengah keatas. Namun data menunjukkan presentase kredit bermasalah pada usaha skala kecil dan mikro terus mengalami penurunan dari tahun ketahun, dibandingkan presentase kredit bermasalah pada sektor usaha skala menengah dan besar yang justru mengalami kenaikan antara tahun 2011 hingga tahun 2013.

Penelitian mengenai deteriman kredit oleh pelaku usaha mikro belum banyak dilakukan, justru banyak penelitian yang dilakukan untuk menganalisis bagaimana pengaruh microcredit terhadap peningkatan kesejahteraan pengusaha mikro, ataupun efektivitas microcredit sebagai strategi pengentasan kemiskinan.

Microcredit merupakan program pembiayaan yang disesain untuk kalangan masyarakat miskin yang sangat keberatan untuk memenuhi persyaratan pembiayaan dari kredit konvensional. Analisis determinan perolehan kredit bagi pengusaha mikro penting untuk dilakukan, untuk kemudian dapat dikembangkan sebagai dasar strategi pengembangan model penyaluran kredit bagi pengusaha mikro yang accesable dengan tetap memperhatikan faktor pelunasan/ pengembalian kredit oleh debitur.

Studi empiris Roslan \& Karim, (2009) mendapatkan bahwa pengembaliaan dari pinjaman/ pembiayaan dipengaruhi oleh kualitas dari peminjam serta berbagai faktor lain, yaitu: tingkat pendidikan, jarak antara pemberi pinjaman dengan lokasi usaha peminjam, jangka waktu pengembalian, gender, dan aturan sanksi yang diberlakukan pada perjanjian kredit. Sementara sebagai saran untuk perluasan akses masyarakat miskin terhadap kredit, Abu-Hadi, et al (2013) menyatakan bahwa penting bagi lembaga-lembaga penyalur microcredit untuk melonggarkan aturan-aturan serta memberlakukan pendampingan khusus bagi pengusaha mikro dalam rangka menjaga angsuran kredit mikro.

Aksebilitas pada microcredit merupakan determinan lain dari efektivitas suatu pinjaman. Tingkat pendidikan, gender, ukuran keluarga, jumlah belanja rumah tanga merupakan beberapa faktor yang mempengaruhi perolehan microcredit kepada masyarakat miskin (Yusuf \& Shirazi, 2013). Kemudian penelitian Ashraf \& Ibrahim (2014) menggunakan faktor determinan gender, usia, status pernikahan, ukuran rumah tangga, pengalaman menjalankan usaha, tingkat pendidikan, dan jumlah pendapatan dalam analisis akseibilitas kredit mikro dalam rangka pengentasan kemiskinan.

Berdasarkan telaah pustaka dan studi empiris terdahulu maka peneliti mengembangkan suatu kerangka yang menggambarkan hubungan antara determinan dengan aksebilitas microcredit, dimana sementara faktor usia responden, gender, jumlah anggota keluarga, tingkat pendidikan, lama menjalankan usaha, omzet Usaha per bulan, jumlah aset, dan laba 
per bulan merupakani variabael dependen sedangkan aksebilitas/ perolehan kredit oleh pengusaha mikro merupakan variabel independen (variabael terikat), untuk lebih jelas kerangka konseptual penelitian tampak pada gambar 1.

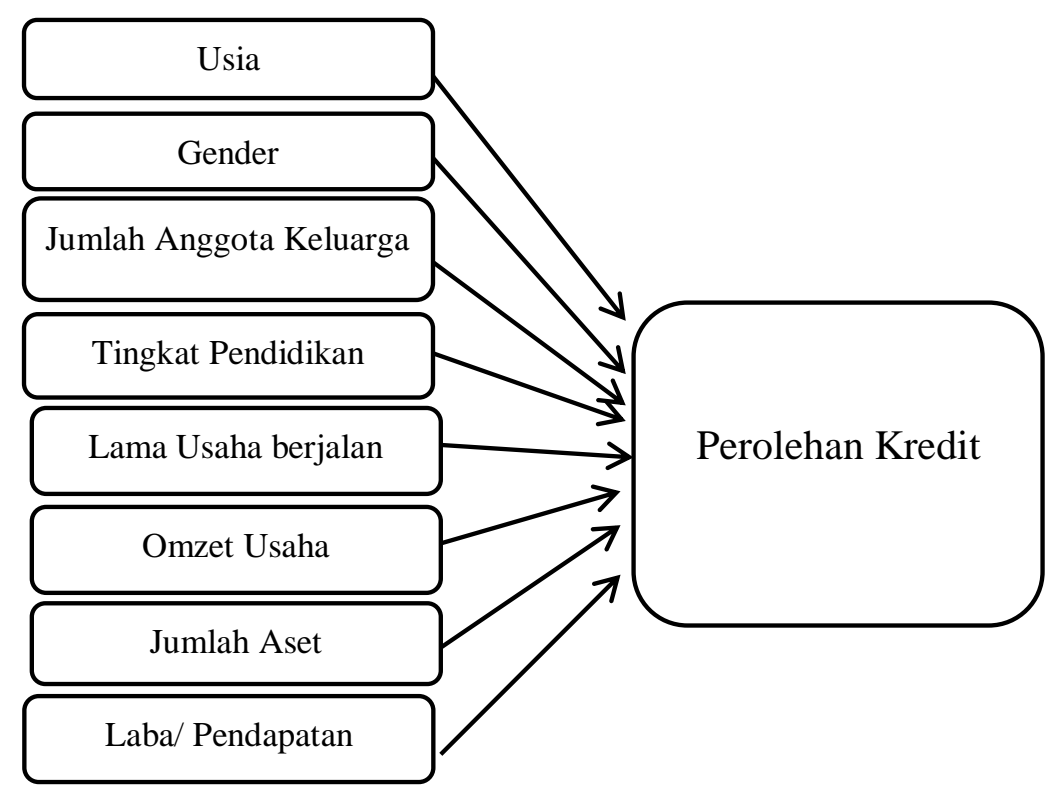

\section{Gambar 1. Kerangka Konseptual Penelitian}

\section{Metode Penelitian}

Populasi penelitian adalah sekumpulan unsur atau elemen yang menjadi obyek penelitian. Biasanya elemen dari populasi merupakan satuan analisis. Populasi merupakan himpunan semua hal yang ingin diketahui oleh peneliti (Sugiyono, 2008). Populasi dari penelitian ini adalah seluruh pengusaha skala mikro di Kabupaten Bojonegoro. Sementara sampel penelitian akan menggunakan sejumlah 200 pengusaha mikro yang diambil secara acak daerah/ probabilistik area sampling yang mewakili seluruh kecamatan di Kabupaten Bojonegoro.

Seperti telah disampaikan sebelumnya bahwa tujuan dari penelitian ini adalah untuk mengungkapkan faktor-faktor yang mempengaruhi perolehan kredit bagi pelaku usaha mikro didaerah Bojonegoro, sehingga lokasi dari penelitian adalah di Kabupaten Bojonegoro.

Data yang digunakan dalam penelitian ini merupakan data primer yang didapatkan langsung dari sampel penelitian dengan metode kuseioner dan wawancara dengan pelaku usaha mikro di Kabupaten Bojonegoro. Kuesioner adalah teknik pengumpulan data yang dilakukan dengan cara memberikan seperangkat pertanyaan atau pernyataan kepada orang lain yang dijadikan responden untuk dijawabnya (Sugiyono, 2008).

Untuk mengidentifikasi faktor-faktor determinan aksebilitas kredit oleh para pengusaha mikro di area penelitian, peneliti mengadopsi model logistic regression. Logit \& probit model merupakan model pilihan biner yang biasanya digunakan dalam analisis aksebilitas kredit di berbagai literatur (Xia, Chistopher, \& Baiding, 2011), dikarenakan bahwa variabel dependen dari penelitian tersebut adalah dikotomi, maka tidak relevan jika analisis menggunakan model regresi linear berganda.

Mengacu pada model regresi logit (Gujarati \& Potter, 2009) persamaan regresi natural logaritma dalam penelitian adalah sebagai berikut: 
$L i=\ln \left(\frac{P_{i}}{1-P_{i}}\right)=Z_{i}=B_{0}+B_{j} \sum_{j=1}^{k} X_{i}+u_{i}$

Dimana nilai $\mathrm{Zi}$ merupakan variabel dependen dalam penelitian dan berupa data dikotomi (ya atau tidak) sedangkan Xi (X1, X2, X3,... Xn ) merupkan variabel independen dalam penelitian.

Model regresi logit yang digunakan juga mengadopsi dari penelitian Xia, Chistopher, \& Baiding, (2011). Dimana persamaan statistik dapat dijabarkan sebagai berikut:

$L i=\ln \left(\frac{P_{i}}{1-P_{i}}\right)=f\left(X_{1}, X_{2}, X_{3}, X_{4}, X_{5 i}, X_{6}, X_{7}, X_{8}\right)$

Pi merupakan variabel dependen binner, $\mathrm{Pi}=1$; jika responden merupakan pengusaha mikro yang pernah mendapatkan pembiayaan/ kredit mikro dari perbankan, dan $\mathrm{Pi}=0$; jika responden belum pernah menerima pembiayaan/ kredit mikro namun pernah mengajukan ke perbankan.

$\mathrm{X} 1$ = Usia responden

$\mathrm{X} 2=$ Gender

$\mathrm{X} 3$ = Jumlah anggota keluarga

$\mathrm{X} 4=$ Tingkat pendidikan

X5 = Lama menjalankan usaha

$\mathrm{X} 6=$ Omzet Usaha per bulan

X7 = Jumlah Aset

$\mathrm{X} 8=\mathrm{Laba} /$ pendapatan per bulan

Aksebilitas kredit mikro merupakan variabel dependen dari penelitian, sementara usia responden, gender, jumlah anggota keluarga, tingkat pendidikan, lama menjalankan usaha, omzet usaha per bulan, jumlah aset, dan laba per bulan merupakan variabel independen penelitian.

Tahap selanjutnya adalah menjabarkan definisi operasional variabel. Definisi Operasional dari masing-masing variabel dalam penelitian ini meliputi:

1. Variabel bebas (X) dalam penelitian ini adalah variabel determinan dalam analisis microcredit mengadopsi pada variabel penelitian Xia, Chistopher, \& Baiding, (2011), dimana variabel bebas terdiri dari usia responden, gender, jumlah anggota keluarga, tingkat pendidikan, lama menjalankan usaha, omzet usaha per bulan, jumlah aset, dan laba per bulan merupakan variabel independen penelitian.

2. Variabel terikat (Y), yang menjadi variabel Y dalam penelitian ini Aksebilitas pembiayaan oleh para pengusaha mikro di Kabupaten Bojonegoro, didapatkan data binner pada variabel tersbut yaitu pernah mendapatkan pembiayaan mikro atau tidak pernah mendapatkan pembiayaan namun pernah mengajukan pada berbagai lembaga microfinance baik bank ataupun bentuk lembaga microfinance lainnya.

\section{Hasil Penelitian dan Pembahasan}

Peneliti telah melakukan survey terhadap 287 responden pengusaha mikro di Kabupaten Bojonegoro melalui metode pengisisan survey dan juga wawancara secara langsung. Sejumlah 77 responden harus dikeluarkan dari sampel penelitian karena merupakan pengusaha mikro yang belum pernah mengajukan kredit ke perbankan. Sebelum dilakukan uji pengaruh antara variabel dependen dan variabel independen penelitian peneliti terlebih dahulu melakukan analisis deskriptif terhadap data yang didapatkan dari responden. 
Dari tabel 1 tampak bahwa responden terdiri dari $46 \%$ pria dan $54 \%$ adalah wanita dari total pengusaha mikro sebagai sampel penelitian. Sementara mayoritas responden adalah pengusaha mikro berusia 41-55 tahun, hal ini menunjukan sebagian besar sampel penelitian merupakan pengusaha mikro yang berada pada usia produktif.

Tabel 4. Deskriptif dari Responden

\begin{tabular}{|c|c|}
\hline & Total sample \\
\hline & $210(100 \%)$ \\
\hline \multicolumn{2}{|l|}{ Jenis Kelamain } \\
\hline 1. Pria & $45.9 \%$ \\
\hline 2. Wanita & $54.1 \%$ \\
\hline \multicolumn{2}{|l|}{ Usia } \\
\hline 1. Kurang dari 25 Tahun & $18.1 \%$ \\
\hline 2. 25-40 tahun & $27.1 \%$ \\
\hline $3.41-55$ tahun & $37.6 \%$ \\
\hline 4. Lebih dari 55 tahun & $17.1 \%$ \\
\hline \multicolumn{2}{|l|}{ Pendidikan } \\
\hline 1. Sekolah Dasar & $30.0 \%$ \\
\hline 2. SLTP & $25.2 \%$ \\
\hline 3. SMA & $22.4 \%$ \\
\hline 4. Diploma/ Sarjana & $22.4 \%$ \\
\hline \multicolumn{2}{|l|}{ Pengalaman Berwirausaha } \\
\hline 1. kurang dari 3 tahun & $4.3 \%$ \\
\hline 2.3-5 tahun & $31.4 \%$ \\
\hline 3. $5-10$ tahun & $39.0 \%$ \\
\hline 4. lebih dari 10 tahun & $25.2 \%$ \\
\hline \multicolumn{2}{|l|}{ Jumlah Karyawan } \\
\hline 1. $1-4$ Orang & $40.0 \%$ \\
\hline 2. 5-19 orang & $39.0 \%$ \\
\hline 3. $20-49$ orang & $9.5 \%$ \\
\hline 4. lebih dari 50 orang & $11.4 \%$ \\
\hline \multicolumn{2}{|l|}{ Omzet perbulan } \\
\hline $1 . \leq 10$ Juta Rupiah & $49.0 \%$ \\
\hline 2. 10-25 Juta Rupiah & $35.7 \%$ \\
\hline 3. 25-100 Juta Rupiah & $12.4 \%$ \\
\hline 4. > 100 Juta Rupiah & $2.9 \%$ \\
\hline \multicolumn{2}{|l|}{ Laba Bersih perbulan } \\
\hline $1 . . \leq 1$ Juta Rupiah & $40.0 \%$ \\
\hline 2. 1-2,5 Juta Rupiah & $39.5 \%$ \\
\hline 3. 2,5-10 Juta Rupiah & $13.8 \%$ \\
\hline 4. > 10 Juta Rupiah & $6.7 \%$ \\
\hline \multicolumn{2}{|l|}{ Jumlah Anggota Keluarga } \\
\hline 1. $1-3$ Orang & $46.2 \%$ \\
\hline 2. 4-5 Orang & $47.6 \%$ \\
\hline 3. Lebih dari 5 orang & $6.2 \%$ \\
\hline
\end{tabular}

Hasil pengujian statistik dengan metode binary logistic regression variabel-variabel yang mempengaruhi perolehan kredit oleh pengusaha mikro disajikan dalem tabel 6 
penelitian. Hasil dari 8 variabel yang diuji, didapatkan variabel tingkat pendidikan, dan laba bersih per bulan berpengaruh signifikan pada level 5\% terhadap perolehan kredit pengusaha mikro, sementara variabel lama usaha berjalan berpengaruh signifikan pada level $10 \%$.

Tabel 5. Hasil Regresi Logistic Faktor Faktor yang mempengaruhi Perolehan Kredit Oleh Pengusaha Mikro

\begin{tabular}{lll}
\hline Variables & Estimated coefficients & Sig \\
\hline Jenis kelamin & 0.287 & 0.674 \\
Usia & -0.149 & 0.465 \\
Tingkat pendidikan & $0.128^{*}$ & 0.035 \\
Lama usaha berjalan & $0.170^{* *}$ & 0.082 \\
Jumlah karyawan & 0.151 & 0.644 \\
Omzet per bulan & 0.180 & 0.533 \\
Laba bersih perbulan & $0.163^{*}$ & 0.302 \\
Jumlah Anggota Keluarga & -0.239 & 0.431 \\
\hline Mc Fadden R-Squared $($ Pseudo $) R^{2}$ & 0.052 & \\
\hline
\end{tabular}

*variable significant at $5 \%, * *$ variable significant at $10 \%$

Tabel 5 menunjukkan bahwa koefisien dari variable level pendidikan, pengalaman berwirausaha, dan laba bersih perbulan memiliki pengaruh positif dan signifikan pada tingkat signifikasi masing-masing. Sementara variabel jenis kelamin, jumlah karyawan, dan omzet usaha perbulan memiliki koefisien positif namun tidak signifikan.

Hasil analisis yang mendapatkan keofisien postif mengindikasikan peningkatan nilai dari masing-masing variabel meningkatkan peluang dari pengajuan kredit yang diajukan oleh para pengusaha mikro untuk disetujui, dan juga sebaliknya semakin kecil nilai variabel tersebut akan menghambat peluang perolehan kredit untuk para pengusaha mikro. Nilai positif dan signifikan dari variabel tingkat pendidikan dan pengalaman berwirausaha terhadap perolahan kredit mikro mendukung hasil penelitian sebelumnya oleh Phan (2012). Hasil empiris serupa yang menyatakan laba bersih, jenis kelamin, jumlah karyawan berpengaruh signifikan terhadap perolehan kredit mikro juga disampaikan Obesisan and Akinlade (2013) dan (Kasali et al., 2016).

Sementara hasil analisis yang mendapatkan variabel usia (-0.149) dan jumlah anggota keluarga (-0.239) berpengaruh negatif walaupun tidak signifikan mengindikasikan peluang pengusaha mikro untuk memperoleh kredit semakin kecil seiring dengan bertambahnya usia serta bertambahnya jumlah anggota keluarga, hal ini mendukung hasil penelitian Xia, Chistopher, \& Baiding, (2011).

\section{Kesimpulan}

Penelitian ini melakukan analisis beberapa faktor yang mempengaruhi perolehan krdit oleh pengusaha mikro di daerah Bojonegoro. Hasil analisis mendapatkan bahwa dari delapan variabel yang diteliti hanya tiga variabel yang terbukti berpengaruh signifkan terhadap akses kredit pengusaha mikro, yaitu variabel tingkat pendidikan, pengalaman berwirausaha dan laba bersih usaha yang dijalankan.

Berdasarkan temuan penelitian ini disarankan pemerintah seharusnya menyediakan model pembiayaan atau kredit yang lebih mendukung pada sektor pengusaha mikro, khususnya untuk para pengusaha mikro yang masih memiliki kendala seperti laba bersih perbulan yang masih relatif kecil, para pengusaha yang masih minim pengalaman berwirausaha. 


\section{DAFTAR PUSTAKA}

Ali, A.H., Abu Hadi, A, O., \& Ali, A. Y. S. (2013). The Accesibility of Microfinance for Small Business in Mogadishu, Somalia, International Journal of Hummanities, and Social Science, Vol 3, No.11 PP. 172-180.

Ashraf, M.A., \& Ibrahim Y. B. (2014) Poverty Allevation and Identifying The Barriers to The Rural Poor Participation in Microfinance: A Case Study in Bangladesh, Journal of Economic Cooperation and Development, Vol.35 No.3, pp 99-132.

Bank Indonesia, (2017) Perkembangan Baki Debet Kredit Usaha Mikro, Kecil, dan Menengah (UMKM) Perbankan.

Firdaus R. \& Maya Ariyanti (2004) Manajemen Perkreditan Bank Umum: Teori, Masalah, Kebijakan dan Aplikasinya Lengkap dan Analisis Kredit, Alfabeta, Bandung.

Gujarati, N. \& Porter, D.C. (2009) Basic Econometrics, Singapore, McGraw-Hill.

Haryadi, A. (2006). Developing Mikrotakaful in Indonesia. In The 2nd International Convention on Takaful and Retakaful, Kuala Lumpur (pp. 1-12).

Jhonson, Don Jr., \& Morduch J., (2008), The Unbanked: Evidence From Indonesia, World Bank Economic Review, Vol. 22 No.3 pp 517-537.

Kalrajan K., \& Singh. K., (2009), The Pace of Poverty Reduction Across The Globe: an Exploratory Analysis, International Journal of Social Economics, Vol.36 No.6, pp 692705.

Kasali, T. A., Aznor, S. A., \& Lim, H. E. (2016). Determinants of Microcredit Access: Empirical Analysis from South-West Nigeria. Journal of Economic Cooperation and Development, 37(4), 125-148.

Kementrian Koperasi dan UMKM, 2014, Profil Bisnis Usaha Mikro, Kecil Dan Menengah (UMKM), Tahun 2014.

Khoiruddin, R., \& Heryanto, S. (2015). Dampak Program Nasional Pemberdayaan Masyarakat Mandiri Perdesaan ( PNPM-MP ) Program Simpan Pinjam Perempuan (SPP) Terhadap Kesejahteraan Keluarga Di Desa Canga'an Kecamatan Kanor Kabupaten Bojonegoro. J+plus UNESA, 4(1), 1-13.

Kung'u, G, N., (2015) Factors bInfluencing Small and Medium Enterprises' Access to Funding in Kenya: A Case Study of Westland Divisions.

Merton, R. (1987). A Simple Model of Capital Market Wquilibium with Incomplete Information, Journal of Finance, 42 (3), 483-150

Nengsih, N. (2015). Peran perbankan syariah dalam mengimplementasikan keuangan inklusif di indonesia. Etikonomi, 14(2), 221-240.

Roslan, A. \& Abd. Karim (2009). Determinats of Microcredit Repayment in Malaysia: The Case of Agrobank, Humanity and Social Sciences Journal,Vol.4 No.1, pp 44-52.

Setyari, Ni Putu W., (2012) Evaluasi Dampak Kredit Mikro Terhadap Kesejahteraan Rumah Tangga di Indonesia: Analisis Data Panel, Jurnal Ekonomi Kuantitatif Terapan, Vol.5, No.2, Hal 141-150.

Sutrisno , Joko., \& Lestari, Sri. (2006), Kajian Usaha Mikro Indonesia, Jurnal Pengkajian Koperasi dan UKM, 1 (2), hal 13-25.

Undang-Undang RI No.20 Tahun 2008, Tentang Usaha Mikro, Kecil dan Menengah.

Wanjohi, M. Anthony (2009), Challenges Facing SMEs in Kenya, www.buzzle.com.

Xia Li, Christopher Gan and Baiding $\mathrm{Hu}$, (2011) The welfare impact of microcredit on rural households in China, Journal of Behavioral and Experimental Economics, vol. 40, issue 4, pages 404-411

Yulistiyono, H. (2015). Implementasi Program Gerdu Taskin Terhadap Pemberdayaan Lembaga Keuangan Mikro di Jawa Timur (Studi Kasus Kabupaten Bojonegoro dan Tuban ). Media Trend, 10(2), 196-216. 
Yusuf, M. B. O., \& Shirazi N. S., (2013), The Impact of Pakistan Poverty Alleviation Fund on Poverty in Pakistan: An Empirical Analysis, Middle East Journal of Scientific Research, Vol.13No.10, pp:1335-1344. 